\title{
A case report of asymptomatic transient biventricular dysfunction after pericardiocentesis: importance of echocardiographic follow-up
}

\author{
Irena Ivanac Vranešić*, \\ Majda Vrkić Kirhmajer, \\ Krešimir Putarek, \\ Ljiljana Banfić
}

University of Zagreb School of Medicine, University Hos pital Centre Zagreb, Zagreb, Croatia

RECEIVED:

August 28, 2015

ACCEPTED:

September 17, 2015

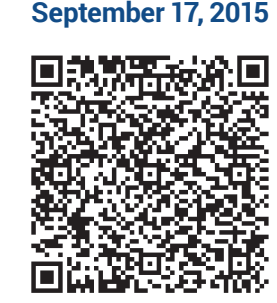

KEYWORDS: pericardiocentesis, tamponade, ventricular dysfunction, left ventricular thrombus, pulmonary adenocarcinoma.

CITATION: Cardiol Croat. 2015;10(9-10):214. | DOI: http://dx.doi.org/10.15836/ccar.2015.214

*ADDRESS FOR CORRESPONDENCE: Irena Ivanac Vranešić, Klinički bolnički centar Zagreb, Kišpatićeva 12, HR-10000 Zagreb, Croatia. / Phone: +385-91-505-9303 / E-mail: irena.ivanac@gmail.com

ORCID: Irena Ivanac Vranešić, http://orcid.org/0000-0002-6910-9720 • Majda Vrkić Kirhmajer, http://orcid.org/0000-0002-1340-1917 Krešimir Putarek, http://orcid.org/0000-0003-0361-5740 • Ljiljana Banfić, http://orcid.org/0000-0002-4538-8980

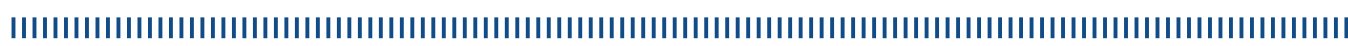

BACKGROUND: Transient ventricular dysfunction (TVD) is rare and potentially fatal complication of pericardiocentesis (PCC). Some authors refer to it as a pericardial decompression syndrome, others call it the stress cardiomyopathy (SCM). The most prevalent pathophysiologic hypothesis states that sudden increase in ventricular preload with concomitantly increased afterload (sympathetic drive) leads to TVD. ${ }^{1-3}$ We present a case of asymptomatic TVD with classical features of SCM after PCC for imminent cardiac tamponade.

CASE REPORT: 49-year-old female presented with 1 month history of chest pain, dyspnea and dry cough. Clinical exam revealed BP of 140/80 mmHg, distended jugular veins, hepatomegaly and muffled heart sounds. ECG showed sinus tachycardia 101/min and microvoltage. Echocardiographycally a large pericardial effusion (PE) with signs of cardiac tamponade was found and PCC was attempted. Only 100 $\mathrm{ml}$ of serosanguinous fluid was evacuated and since the patient was clinically stable we postponed the new PCC for the next day. Patient felt significantly better. The follow-up echocardiographic exam showed that the PE had drained into the left pleural cavity and that there was a newly developed apical biventricular akinesis with left ventricular apical thrombus. Cardiac enzymes were slightly elevated and ECG showed inverted $\mathrm{T}$ waves in all precordial leads. Treatment with enoxaparin, furosemide and bisoprolol was started. Chest CT scan and PE fluid analysis revealed metastatic pulmonary adenocarcinoma. Ten days after PCC, complete recovery of systolic function as well as complete resolution of the thrombus was found and patient was transferred to the pulmonary clinic for further treatment.

CONCLUSION: TVD is a rare complication of PCC and is more frequently observed in patients with rapid drainage of large PE. Since TVD can be asymptomatic, regular echocardiographic follow up after PCC is important in order to reveal potential complications and to guide optimal treatment.

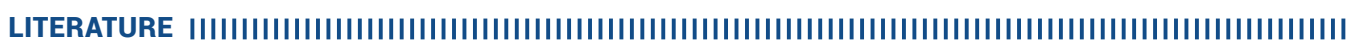

1. Chadi A, Chang M, Kritharides L. A case report of ventricular dysfunction post pericardiocentesis: stress cardiomyopathy or pericardail decompression syndrome? Cardiovasc Ultrasound. 2015 Jul 16;13:32. DOI: http://dx.doi.org/10.1186/s12947-015-0026-3

2. Chamoun A, Cenz R, Mager A, Rahman A, Champion C, Ahmad M, et al. Acute left ventricular failure after large volume pericardiocentesis. Clin. Cardiol. 2003;26:588-90. DOI: http://dx.doi.org/10.1002/clc.4960261209

3. Moreno Flores V, Pascual Figal DA, Caro Martínez C, Valdés-Chávarri M. Transient left ventricular dysfunction following pericardiocentesis. An unusual complication to bear in mind. Rev Esp Cardiol. 2009;62(9):1071-2. DOI: http://dx.doi.org/10.1016/S1885-5857(09)73277-3 